\title{
Ear Spray Suspension Dosage Form
}

National Cancer Institute

\section{Source}

National Cancer Institute. Ear Spray Suspension Dosage Form. NCI Thesaurus. Code C149461.

Liquid, usually multidose preparation consisting of a suspension intended for application to the external auditory meatus by spraying to obtain a local effect. Ear sprays are presented in containers with a spray pump or in pressurized containers fitted with a spray valve. 